\title{
The Influence of Employment on the Socio-Economic Empowerment of Urban Women in Bangladesh
}

\author{
Samia Shabnaz ${ }^{1}$, Tahsina Khan ${ }^{2}$, Bohi Shajahan ${ }^{3}$ \\ ${ }^{1}$ (Management, American International University-Bangladesh, Bangladesh) \\ ${ }^{2}$ (Marketing, American International University-Bangladesh, Bangladesh) \\ ${ }^{3}$ (Finance, American International University-Bangladesh, Bangladesh)
}

\begin{abstract}
In a patriarchal social structure like Bangladesh the role of women is confined to some definite work and position which is considered inferior to that of men. Even after numerous progresses in gender relation, the situation more or less remains the same in the context of their family roles and responsibilities that cause domestic violence. This is an empirical study that aims to identify the relationship between employment and women's empowerment in urban areas of Bangladesh. Women's "empowerment" in developing countries gained attention due to its significant influence in socio economic development of the country. The data has been collected using Non-probability purposive sampling technique from a total of 100 respondents in Dhaka city. Among them 50 were employed and 50 were unemployed women. To collect the primary data the questionnaire was designed using structured questionnaire to assess women's empowerment with relation to their employment status. The result of this study suggests that the employed women have a greater likelihood of higher empowerment than unemployed women; however the relationship varies between empowerment indicators. This study will provide an insight into the factors that needs to be addressed to strengthen women empowerment in urban society.
\end{abstract}

Keywords: Employed Women, Unemployed Women, Urban Middle Class, Women Empowerment,

\section{Introduction}

In Bangladesh women have low status in comparison with men even if they contribute in the development activity. As women comprise about half of the total population Bangladesh development process will not get pace without the further involvement of the women [1]. But the women of this country often experience mistreatment than men through the rules, regulations, customs and society. This unreasonable behavior gives women lower status in terms of men socially, culturally, religiously, economically and legally[2]. Thus, empowering women is critical since it will help to unlock their potentials, which in turn enable them to improve not only their standard of living and quality of life, but also the welfare of their family.

Women's empowerment is the process and the outcome of the process, by which women gain greater control over material and intellectual resources and challenge the ideology of patriarchy and the gender based discrimination against women in all the institutions and structures of society [3]. The women who are involved in any income related activities or who contribute in the family income they are more empowered than the women who are not engaged in any income related activities [4][5]. However study by several researchers indicated that simply being employed is probably not enough to ensure women's empowerment because working does not necessarily allow women to challenge the power structures that prevent their agency and full participation in society [6][7][8][9].

According to the Labor Force Survey 2010, around 4 million women are employed in the urban area [10]. however BBS (Bangladesh Bureau of Statistics) study report on violence against women (VAW) survey 2011, published in (2013) found that $85 \%$ of women in Bangladesh have no freedom to earn money of their own selves. Only 15\% women get the freedom to earn with their own willing and those who earn only $24 \%$ have own control on their earnings. The woman who lives in rural as well as urban area has similar chance to be victimized by domestic violence [11]. A research which attempted to investigate the prevalence, nature and determinants of violence against women found that $80 \%$ women in the survey and $71 \%$ women in the in-depth interview reported to have been physically, sexually, emotionally, mentally abused throughout their marital lives[12].

Several researches have been conducted to analyze the influence of income generating activities and microcredit on women empowerment. However most of the studies focused on rural women from lower income group but very few research have been done on the empowerment status of the urban women in the middle income group. Thus the objective of this research is to know the role of employment on several dimensions of women empowerment for urban middle income group. The rest of the paper will discuss the current literature followed by methodology and analysis. Finally it will be concluded with recommendation and provide future research direction. 


\section{Literature Review}

The concept of 'empowerment' is complex as its meaning varies depending on the socio-cultural as well as political contexts and hence, it is difficult to furnish a unique definition of empowerment. Empowerment can be defined as the expansion in people's ability to make strategic life choices in a context where this ability was previously denied to them [13]. Empowerment of women has been defined as a process through which women in disadvantaged positions increase their access to knowledge, resources, decision-making power and raise their awareness of participation in their own communities in order to have control over their own environments [14]. "Empowerment is about change in favor of those who previously exercised little control over their lives. This has two sides. The first is control over resources (financial, physical and human). The second is control over ideology (beliefs, values and attitudes) [15].

Empowerment is a process which enables women to meet both their practical and strategic needs and increases women's political power, consciousness about them and strengthens women's self confidence [5][16]. A research reveals that empowerment means the process which requires change at different levels and in different dimensions: change at the individual level and change in their 'inner' sense of self or in their access to material resources and relationships within the family and household [17]. Women empowerment consists of greater access to knowledge and resources, greater autonomy in decision making to enable them to have greater ability to plan their lives, or to have greater control over the circumstances that influence their lives and free from shocks imposed on them by custom, belief and practice [18].

Literature reveals that many authors have provided different measures regarding what constitutes women empowerment. It can include her mobility, intra-household decision making power and general attitudes about her children's lives [19[20] as well as on her control over resources and incidence of domestic violence [21]. Based on various suggestions in the development literature [22][20], woman empowerment is measured by seven dimensions which are: (i) decision making in the family (ii) access to resources (iii) control over resources, (iv) Mobility (v) self respect (vi) Legal and political awareness (vii) familial and interpersonal.

Several researchers indicated that income-generating activities raise women's decision making power in the household and community [23][24][25]. The women who are entrepreneur or engaged in the development of entrepreneurship activities in Bangladesh are more socially, politically and economically empowered [1]. Studies on microcredit pointed out that micro credit has positive impacts were enhancement in women's ability to influence family affairs and decision making; increasing self-confidence; improvement in their status, increased gender relations in the home, reduction in domestic violence, and improvement in status within the community and acceleration in economic empowerment [26][27]. Several researchers mentioned in their study that the impact of women's empowerment and social security has been invariably improved because of microcredit [28][29]. According to Zaman, empowerment of women was achieved by giving them control over assets and increased self-esteem and knowledge [30]. Studies found that economic factors have the greatest direct impact on empowering women [31] [32]. This confirms that programs such as SHGs, which focus on the income generation by women in low-income households, have the double advantage of leading to an improved economic situation of the respondent and being the most effective factor in empowering women. However, it was found that greater autonomy and changes in social attitudes also lead to the empowerment of women, although the magnitude of their impact is, relatively, smaller than the economic factor [32].

The women who earn and contribute to the family expenditure are able to exercise their rights and power that increases their self-esteem and self- confidence [33] [34] [35].Studies with women in Bangladesh report that paid work is empowering women to have decision- making in the home, control resources, have greater mobility and are better able to accumulate assets and secure their own well-being [36] [37]. However empowerment is also impeded because women's employment is often survival-driven and does not affect changes in gender relations, women's low earnings do not offer them entitlements to social protection, employment does not relieve the burden of domestic labor, it does not increase political participation and it does not lead to equal property rights [9][38]. Despite these barriers, literature available on this particular field summarizes that employment, under the right conditions, can be an important factor in the promotion of women's empowerment.

\section{Methodology}

The population of the study has been selected based on certain criteria. The study targeted married women of middle to higher income group with age range from 25 to 45 years and minimum educational qualification as graduate. In order to collect data $\mathbf{1 0 0}$ sample was selected where equal numbers of employed and unemployed women were studied. Non-probability purposive sampling technique has been used to collect data from these two groups of respondent.

Data and information has been collected through questionnaire survey and interviews. To collect the primary data structured questionnaire was designed to assess women's empowerment with relation to their employment status. As the questionnaire used for data collection was designed rather than adopted from an 
existing research, a reliability test was thought necessary. The Cronbach Alpha testing was used as it is the most well accepted reliability test tools applied by social researcher [39]. The questionnaire used in this research is considered good as its value is 0.90 . This study attempts to analyze the women empowerment related with employment. The analysis of this research was conducted using SPSS 20.0. The analysis incorporated basic descriptive statistics and crosstab.

\section{Analysis}

From TABLE 1 it is evident that most of the respondents from both employed and unemployed category belong to age group 25-35 (68\% for unemployed and 78\% for employed).Looking in to the education of the respondents, it is observed that most employed women (76\%) and unemployed women (62\%) have post graduation degree. A significant number of respondents from employed (54\%) and unemployed (56\%) women have family size of 2-4. With respect to family income most of the respondents from employed category (52\%) have a family income of more than Tk 100000 which is much higher than unemployed respondents (18\%). For the unemployed group majority (76\%) of them have monthly income between the range Tk.30, 000 to Tk. $1,00,000$.

Table 1: Demographic Characteristics

\begin{tabular}{|c|c|c|c|c|c|}
\hline & & \multicolumn{2}{|c|}{ Employed } & \multicolumn{2}{|c|}{ Unemployed } \\
\hline Demographic Factors & & Frequency & Percentage & Frequency & Percentage \\
\hline \multirow[t]{5}{*}{ Age } & $25-30$ & 16 & $32 \%$ & 19 & $38 \%$ \\
\hline & $31-35$ & 23 & $46 \%$ & 15 & $30 \%$ \\
\hline & $36-40$ & 6 & $12 \%$ & 14 & $28 \%$ \\
\hline & $41-45$ & 5 & $10 \%$ & 2 & $4 \%$ \\
\hline & Total & 50 & $100 \%$ & 50 & $100 \%$ \\
\hline \multirow[t]{4}{*}{ Education level } & Graduation & 11 & $22 \%$ & 19 & $38 \%$ \\
\hline & Post Graduation & 38 & $76 \%$ & 31 & $62 \%$ \\
\hline & Above Post Graduation & 1 & $2 \%$ & 0 & $0 \%$ \\
\hline & Total & 50 & $100 \%$ & 50 & $100 \%$ \\
\hline \multirow[t]{4}{*}{ Family size } & 2-4 member & 27 & $54 \%$ & 28 & $56 \%$ \\
\hline & 5-7 member & 19 & $38 \%$ & 19 & $38 \%$ \\
\hline & More than 7 member & 4 & $8 \%$ & 3 & $6 \%$ \\
\hline & Total & 50 & $100 \%$ & 50 & $100 \%$ \\
\hline \multirow[t]{4}{*}{ Family Income } & $15000-30000$ & 2 & $4 \%$ & 3 & $6 \%$ \\
\hline & $30000-100000$ & 22 & $44 \%$ & 38 & $76 \%$ \\
\hline & More than 100000 & 26 & $52 \%$ & 9 & $18 \%$ \\
\hline & Total & 50 & $100 \%$ & 50 & $100 \%$ \\
\hline
\end{tabular}

Table 2: Decision of Purchasing Expensive Item

\begin{tabular}{|c|c|c|c|c|c|c|c|c|}
\hline & & & $\begin{array}{l}\text { Other } \\
\text { Family } \\
\text { Member }\end{array}$ & Husband & $\begin{array}{c}\text { husband } \\
\text { but wife } \\
\text { is also } \\
\text { involved }\end{array}$ & $\begin{array}{c}\text { both } \\
\text { Husband } \\
\& \text { Wife }\end{array}$ & Wife & Total \\
\hline \multirow{4}{*}{$\begin{array}{l}\text { Current } \\
\text { Employment } \\
\text { Status }\end{array}$} & \multirow[t]{2}{*}{ Unemployed } & Count & 3 & 12 & 9 & 21 & 5 & 50 \\
\hline & & $\begin{array}{l}\% \text { within Current Employment } \\
\text { Status }\end{array}$ & $6.0 \%$ & $24.0 \%$ & $18.0 \%$ & $42.0 \%$ & $10.0 \%$ & $100.0 \%$ \\
\hline & \multirow[t]{2}{*}{ Employed } & Count & 3 & 2 & 5 & 35 & 5 & 50 \\
\hline & & $\begin{array}{l}\% \text { within Current Employment } \\
\text { Status }\end{array}$ & $6.0 \%$ & $4.0 \%$ & $10.0 \%$ & $70.0 \%$ & $10.0 \%$ & $100.0 \%$ \\
\hline \multirow{2}{*}{\multicolumn{2}{|c|}{ Total }} & Count & 6 & 14 & 14 & 56 & 10 & 100 \\
\hline & & $\begin{array}{l}\% \text { within Current Employment } \\
\text { Status }\end{array}$ & $6.0 \%$ & $14.0 \%$ & $14.0 \%$ & $56.0 \%$ & $10.0 \%$ & $100.0 \%$ \\
\hline
\end{tabular}

Regarding decision making ability in the family, three tables show the distinction between employed and unemployed respondents. With respect to taking decision in purchasing expensive items, TABLE 2 indicates that a significant number of employed women (80\%) have active participation regarding the decision of purchasing expensive items where as it is less for unemployed women (52\%). The evidence of relationship is also significant $\left(X^{2}=11.786, \mathrm{df}=4, \mathrm{p}=0.019\right)$. From TABLE 3 it is observed that a significant number of unemployed women $(27 \%)$ could not participate on decision regarding child health compared to employed women $(0 \%)$. Whereas majority of employed women $(95.2 \%)$ actively participate in decision making regarding child health which is more than that of unemployed women (47.7\%) The significance of the relationship is also indicated in the Chi-Square Test $\left(X^{2}=27.246, \mathrm{df}=3, \mathrm{p}=0.000\right)$. From TABLE 4 it is observed that a significant number of unemployed women (30\%) do not have the opportunity to participate on decision regarding their employment however employed women have active participation in this issue. Even when it comes to sole decision making, the percentage is much higher among employed women (40\%) than unemployed women $(8 \%)$. 
Moreover the relationship is also significant which is apparent in the Chi-Square Test $\left(X^{2}=32.642, \mathrm{df}=4\right.$, $\mathrm{p}=0.000)$

Table 3: Decision on Child Health

\begin{tabular}{|c|c|c|c|c|c|c|c|}
\hline & & & Husband & $\begin{array}{l}\text { husband } \\
\text { but wife } \\
\text { involve }\end{array}$ & $\begin{array}{c}\text { Both } \\
\text { husband \& } \\
\text { wife }\end{array}$ & Wife & Total \\
\hline \multirow{3}{*}{$\begin{array}{l}\text { Current } \\
\text { Employment } \\
\text { Status }\end{array}$} & Unemployed & Count & 12 & 11 & 15 & 6 & 44 \\
\hline & \multirow[t]{2}{*}{ Employed } & Count & 0 & 2 & 36 & 4 & 42 \\
\hline & & $\%$ within Current Employment Status & $.0 \%$ & $4.8 \%$ & $85.7 \%$ & $9.5 \%$ & $100.0 \%$ \\
\hline \multicolumn{2}{|l|}{ Total } & Count & 12 & 13 & 51 & 10 & 86 \\
\hline
\end{tabular}

Table 4: Decision on Respondent's Employment

\begin{tabular}{|c|c|c|c|c|c|c|c|c|}
\hline & & & $\begin{array}{c}\text { Other } \\
\text { family } \\
\text { Members }\end{array}$ & Husband & $\begin{array}{l}\text { husband } \\
\text { but wife } \\
\text { involve }\end{array}$ & $\begin{array}{c}\text { Both } \\
\text { husband } \\
\text { \& wife }\end{array}$ & Wife & Total \\
\hline \multirow{4}{*}{$\begin{array}{l}\text { Current } \\
\text { Employment } \\
\text { Status }\end{array}$} & \multirow[t]{2}{*}{ Unemployed } & Count & 1 & 14 & 15 & 16 & 4 & 50 \\
\hline & & $\begin{array}{l}\% \text { within Current } \\
\text { Employment Status }\end{array}$ & $2.0 \%$ & $28.0 \%$ & $30.0 \%$ & $32.0 \%$ & $8.0 \%$ & $100.0 \%$ \\
\hline & \multirow[t]{2}{*}{ Employed } & Count & 0 & 0 & 5 & 25 & 20 & 50 \\
\hline & & $\begin{array}{l}\% \text { within Current } \\
\text { Employment Status }\end{array}$ & $.0 \%$ & $.0 \%$ & $10.0 \%$ & $50.0 \%$ & $40.0 \%$ & $100.0 \%$ \\
\hline \multirow{2}{*}{\multicolumn{2}{|c|}{ Total }} & Count & 1 & 14 & 20 & 41 & 24 & 100 \\
\hline & & $\begin{array}{l}\% \text { within Current } \\
\text { Employment Status }\end{array}$ & $1.0 \%$ & $14.0 \%$ & $20.0 \%$ & $41.0 \%$ & $24.0 \%$ & $100.0 \%$ \\
\hline
\end{tabular}

Focusing on the respondents ability to access the resources, two tables portrayed the significant variation between employed and unemployed women. In TABLE 5 regarding whether the respondent has access to their own property a significant difference is observed between employed and unemployed women which is evident in the Chi-Square Test $\left(X^{2}=8.797, \mathrm{df}=3, \mathrm{p}=0.032\right)$. A significant portion of employed women can always access their own property which is much higher in comparison to unemployed women (60\%). From TABLE 6 it is observed that a significant number of employed women (74\%) can always save which is much higher than that of unemployed respondents (44\%). Moreover the relationship is also significant which is apparent in the Chi-Square Test $\left(X^{2}=9.542, \mathrm{df}=2, \mathrm{p}=0.008\right)$

Table 5: Does Respondent Have Access to Own Property

\begin{tabular}{|c|c|c|c|c|c|c|c|}
\hline & & & no & sometimes & often & Always & Total \\
\hline \multirow{4}{*}{$\begin{array}{l}\text { Current } \\
\text { Employment Status }\end{array}$} & \multirow[t]{2}{*}{ Unemployed } & Count & 0 & 8 & 12 & 30 & 50 \\
\hline & & $\begin{array}{l}\% \text { within Current } \\
\text { Employment Status }\end{array}$ & $0.0 \%$ & $16.0 \%$ & $24.0 \%$ & $60.0 \%$ & $100.0 \%$ \\
\hline & \multirow[t]{2}{*}{ Employed } & Count & 1 & 5 & 3 & 41 & 50 \\
\hline & & $\begin{array}{l}\text { \% within Current } \\
\text { Employment Status }\end{array}$ & $2.0 \%$ & $10.0 \%$ & $6.0 \%$ & $82.0 \%$ & $100.0 \%$ \\
\hline \multirow[t]{2}{*}{ Total } & & Count & 1 & 13 & 15 & 71 & 100 \\
\hline & & $\begin{array}{l}\text { \% within Current } \\
\text { Employment Status }\end{array}$ & $1.0 \%$ & $13.0 \%$ & $15.0 \%$ & $71.0 \%$ & $100.0 \%$ \\
\hline
\end{tabular}

Table 6: Does Respondent Have Opportunity To Have Own Saving?

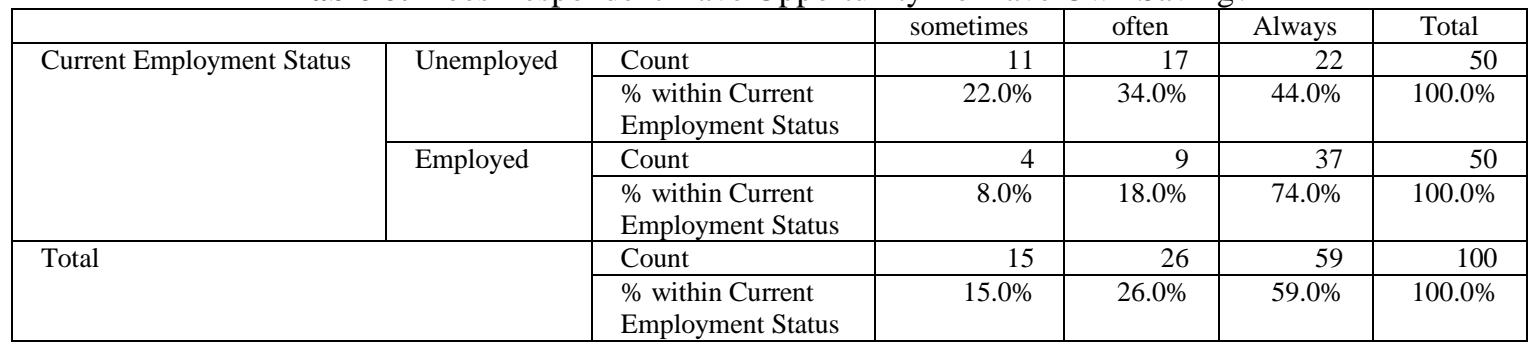

Regarding the control over resources four issues were discussed to identify the disparity between the two groups. Based on who controls the family budget in TABLE 7, the scenario is different for unemployed and employed women. A greater part (44\%) of unemployed women has limited control over the family budget compared to employed women $(22 \%)$ as their husbands or other family members have the control. In case of employed women the significant percentage of respondents indicated that both husband and wife control family 
budget (56\%), which is more than that of unemployed women (22\%). The significance of the relationship is also noteworthy as indicated from the Chi square test $\left(X^{2}=15.092, \mathrm{df}=4, \mathrm{p}=0.005\right)$. Looking into TABLE 8 regarding who purchases routine items it is apparent that for employed women a significant portion of respondents $(82 \%)$ are actively involved in purchasing gift items, however for unemployed the percentage is $52 \%$. The significance of the relationship between employed and unemployed is also high which is clear from the chi square test $\left(X^{2}=13.877, \mathrm{df}=4, \mathrm{p}=0.008\right)$. TABLE 9 compares between unemployed and employed women regarding control over the exchange and sale of their own property. A significant portion of employed women $(76 \%)$ actively participates in controlling their own property compared to that of unemployed women (40\%) and the evidence of relationship is significant in the Chi square test $\left(X^{2}=16.295, \mathrm{df}=4, \mathrm{p}=0.003\right)$. TABLE 10 portrays that a large number of employed women (54\%) can exclusively control their own saving which is comparatively much higher than unemployed women (18\%).The relationship is also significant which is apparent from the Chi square test $\left(X^{2}=9.731, \mathrm{df}=4, \mathrm{p}=0.045\right)$

Table 7: Control of Family Budget

\begin{tabular}{|c|c|c|c|c|c|c|c|c|}
\hline & & & $\begin{array}{c}\text { Other } \\
\text { Family } \\
\text { Member }\end{array}$ & Husband & $\begin{array}{c}\text { husband but } \\
\text { wife is also } \\
\text { involved }\end{array}$ & $\begin{array}{c}\text { both } \\
\text { Husband } \\
\text { \& Wife }\end{array}$ & Wife & Total \\
\hline \multirow{4}{*}{$\begin{array}{l}\text { Current } \\
\text { Employment } \\
\text { Status }\end{array}$} & \multirow[t]{2}{*}{ Unemployed } & Count & 3 & 19 & 12 & 11 & 5 & 50 \\
\hline & & $\begin{array}{l}\% \text { within Current } \\
\text { Employment Status }\end{array}$ & $6.0 \%$ & $38.0 \%$ & $24.0 \%$ & $22.0 \%$ & $10.0 \%$ & $100.0 \%$ \\
\hline & \multirow[t]{2}{*}{ Employed } & Count & 4 & 7 & 6 & 28 & 5 & 50 \\
\hline & & $\begin{array}{l}\text { \% within Current } \\
\text { Employment Status }\end{array}$ & $8.0 \%$ & $14.0 \%$ & $12.0 \%$ & $56.0 \%$ & $10.0 \%$ & $100.0 \%$ \\
\hline \multirow{2}{*}{\multicolumn{2}{|c|}{ Total }} & Count & 7 & 26 & 18 & 39 & 10 & 100 \\
\hline & & $\begin{array}{l}\text { \% within Current } \\
\text { Employment Status }\end{array}$ & $7.0 \%$ & $26.0 \%$ & $18.0 \%$ & $39.0 \%$ & $10.0 \%$ & $100.0 \%$ \\
\hline
\end{tabular}

Table 8: Purchasing Gift Items

\begin{tabular}{|c|c|c|c|c|c|c|c|c|}
\hline & & & $\begin{array}{l}\text { Other } \\
\text { Family } \\
\text { Member }\end{array}$ & Husband & $\begin{array}{l}\text { husband but } \\
\text { wife is also } \\
\text { involved }\end{array}$ & $\begin{array}{l}\text { both } \\
\text { Husband } \\
\text { \& Wife }\end{array}$ & Wife & Total \\
\hline \multirow{3}{*}{$\begin{array}{l}\text { Current } \\
\text { Employment } \\
\text { Status }\end{array}$} & Unemployed & Count & 0 & 4 & 18 & 14 & 14 & 50 \\
\hline & \multirow[t]{2}{*}{ Employed } & Count & 1 & 3 & 5 & 29 & 12 & 50 \\
\hline & & $\begin{array}{l}\% \text { within Current } \\
\text { Employment Status }\end{array}$ & $2.0 \%$ & $6.0 \%$ & $10.0 \%$ & $58.0 \%$ & $24.0 \%$ & $100.0 \%$ \\
\hline \multirow{2}{*}{\multicolumn{2}{|c|}{ Total }} & Count & 1 & 7 & 23 & 43 & 26 & 100 \\
\hline & & $\begin{array}{l}\text { \% within Current } \\
\text { Employment Status }\end{array}$ & $1.0 \%$ & $7.0 \%$ & $23.0 \%$ & $43.0 \%$ & $26.0 \%$ & $100.0 \%$ \\
\hline
\end{tabular}

Table 9: Control Over Own Property

\begin{tabular}{|c|c|c|c|c|c|c|c|c|}
\hline & & & $\begin{array}{c}\text { Other } \\
\text { Family } \\
\text { Member }\end{array}$ & Husband & $\begin{array}{l}\text { husband but } \\
\text { wife is also } \\
\text { involved }\end{array}$ & $\begin{array}{l}\text { both } \\
\text { Husband } \\
\text { \& Wife }\end{array}$ & Wife & Total \\
\hline \multirow{3}{*}{$\begin{array}{l}\text { Current } \\
\text { Employment } \\
\text { Status }\end{array}$} & Unemployed & Count & 2 & 9 & 19 & 15 & 5 & 50 \\
\hline & \multirow[t]{2}{*}{ Employed } & Count & 1 & 4 & 7 & 35 & 3 & 50 \\
\hline & & $\begin{array}{l}\% \text { within Current } \\
\text { Employment Status }\end{array}$ & $2.0 \%$ & $8.0 \%$ & $14.0 \%$ & $70.0 \%$ & $6.0 \%$ & $100.0 \%$ \\
\hline \multirow{2}{*}{\multicolumn{2}{|c|}{ Total }} & Count & 3 & 13 & 26 & 50 & 8 & 100 \\
\hline & & $\begin{array}{l}\% \text { within Current } \\
\text { Employment Status }\end{array}$ & $3.0 \%$ & $13.0 \%$ & $26.0 \%$ & $50.0 \%$ & $8.0 \%$ & $100.0 \%$ \\
\hline
\end{tabular}

Table 10: Control Over Own Saving

\begin{tabular}{|c|c|c|c|c|c|c|c|c|}
\hline & & & $\begin{array}{l}\text { Other } \\
\text { Family } \\
\text { Member }\end{array}$ & Husband & $\begin{array}{l}\text { husband but } \\
\text { wife is also } \\
\text { involved }\end{array}$ & $\begin{array}{c}\text { both } \\
\text { Husband } \\
\text { \& Wife }\end{array}$ & Wife & Total \\
\hline \multirow{4}{*}{$\begin{array}{l}\text { Current } \\
\text { Employment } \\
\text { Status }\end{array}$} & \multirow[t]{2}{*}{ Unemployed } & Count & 1 & 8 & 8 & 24 & 9 & 50 \\
\hline & & $\begin{array}{l}\text { \% within Current } \\
\text { Employment Status }\end{array}$ & $2.0 \%$ & $16.0 \%$ & $16.0 \%$ & $48.0 \%$ & $18.0 \%$ & $100.0 \%$ \\
\hline & \multirow[t]{2}{*}{ Employed } & Count & 0 & 4 & 3 & 16 & 27 & 50 \\
\hline & & $\begin{array}{l}\% \text { within Current } \\
\text { Employment Status }\end{array}$ & $.0 \%$ & $8.0 \%$ & $6.0 \%$ & $32.0 \%$ & $54.0 \%$ & $100.0 \%$ \\
\hline \multirow{2}{*}{\multicolumn{2}{|c|}{ Total }} & Count & 1 & 12 & 11 & 40 & 36 & 100 \\
\hline & & $\begin{array}{l}\% \text { within Current } \\
\text { Employment Status }\end{array}$ & $1.0 \%$ & $12.0 \%$ & $11.0 \%$ & $40.0 \%$ & $36.0 \%$ & $100.0 \%$ \\
\hline
\end{tabular}


On the subject of mobility TABLE 11 represents that $78 \%$ employed women are allowed to go outside alone whereas 54\% unemployed women are practicing freedom in their movement and a strong evidence of relationship is indicated in the Chi square test $\left(X^{2}=7.142, \mathrm{df}=2, \mathrm{p}=0.028\right)$. In TABLE 12 regarding freedom to visit different places a significant difference is observed between employed and unemployed respondents which is evident from the Chi square test $\left(X^{2}=6.596, \mathrm{df}=2, \mathrm{p}=0.037\right)$. In comparing the respondents it is noticeable that $36 \%$ of employed respondents can always visit but for unemployed the percentage is only $14 \%$.

Table 11: Mobility with or without Escort

\begin{tabular}{|c|c|c|c|c|c|c|}
\hline & & & allowed with any adult & allowed with child & alone & Total \\
\hline \multirow{2}{*}{$\begin{array}{l}\text { Current } \\
\text { Employment } \\
\text { Status }\end{array}$} & Unemployed & Count & 13 & 10 & 27 & 50 \\
\hline & Employed & $\begin{array}{l}\text { \% within Current } \\
\text { Employment Status }\end{array}$ & $16.0 \%$ & $6.0 \%$ & $78.0 \%$ & $100.0 \%$ \\
\hline \multicolumn{2}{|l|}{ Total } & Count & 21 & 13 & 66 & 100 \\
\hline
\end{tabular}

Table 12: Mobility to Visit Five Different Places

\begin{tabular}{|c|c|c|c|c|c|c|}
\hline & & & sometimes & often & always & Total \\
\hline \multirow{4}{*}{$\begin{array}{l}\text { Current } \\
\text { Employme } \\
\text { nt Status }\end{array}$} & \multirow[t]{2}{*}{ Unemployed } & Count & 18 & 25 & 7 & 50 \\
\hline & & $\%$ within Current Employment Status & $36.0 \%$ & $50.0 \%$ & $14.0 \%$ & $100.0 \%$ \\
\hline & \multirow[t]{2}{*}{ Employed } & Count & 12 & 20 & 18 & 50 \\
\hline & & $\%$ within Current Employment Status & $24.0 \%$ & $40.0 \%$ & $36.0 \%$ & $100.0 \%$ \\
\hline \multirow{2}{*}{\multicolumn{2}{|c|}{ Total }} & Count & 30 & 45 & 25 & 100 \\
\hline & & $\%$ within Current Employment Status & $30.0 \%$ & $45.0 \%$ & $25.0 \%$ & $100.0 \%$ \\
\hline
\end{tabular}

According to the aspect of self-respect TABLE 13 depicts the comparative scenario of men's participation in household chores between respondents' group of unemployed and employed women. A greater percentage of employed women (48\%) consider that men should always take part in household chores. Majority of the women from the unemployed group (52\%) perceives that men should be sometimes involved with the household chores. The significance of this relationship is also evident from the Chi square test $\left(X^{2}=11.129, \mathrm{df}=\right.$ $3, \mathrm{p}=0.011$ ). From TABLE 14 it is observed that $44 \%$ of employed respondents always get appreciation from family but for unemployed the percentage is only $34 \%$. The chi square test $\left(X^{2}=11.828, \mathrm{df}=3, \mathrm{p}=0.008\right)$ also reveals the significance of the relationship.

Table 13: Opinion about Men's Participate in Household Chores

\begin{tabular}{|c|c|c|c|c|c|c|c|}
\hline & & & not at all & sometimes & often & always & Total \\
\hline \multirow{2}{*}{$\begin{array}{l}\text { Current } \\
\text { Employment } \\
\text { Status }\end{array}$} & Unemployed & Count & 1 & 26 & 14 & 9 & 50 \\
\hline & Employed & Count & 0 & 15 & 11 & 24 & 50 \\
\hline \multirow{2}{*}{\multicolumn{2}{|c|}{ Total }} & Count & 1 & 41 & 25 & 33 & 100 \\
\hline & & $\%$ within Current Employment Status & $1.0 \%$ & $41.0 \%$ & $25.0 \%$ & $33.0 \%$ & $100.0 \%$ \\
\hline \multicolumn{8}{|c|}{ Table 14: Do you get Appreciation from Family? } \\
\hline \multirow{4}{*}{$\begin{array}{l}\text { Current } \\
\text { Employment } \\
\text { Status }\end{array}$} & \multirow[t]{2}{*}{ Unemployed } & Count & 1 & 21 & 11 & 17 & 50 \\
\hline & & $\%$ within Current Employment Status & $2.0 \%$ & $42.0 \%$ & $22.0 \%$ & $34.0 \%$ & $100.0 \%$ \\
\hline & \multirow[t]{2}{*}{ Employed } & Count & 6 & 7 & 15 & 22 & 50 \\
\hline & & $\%$ within Current Employment Status & $12.0 \%$ & $14.0 \%$ & $30.0 \%$ & $44.0 \%$ & $100.0 \%$ \\
\hline \multirow{2}{*}{\multicolumn{2}{|c|}{ Total }} & Count & 7 & 28 & 26 & 39 & 100 \\
\hline & & $\%$ within Current Employment Status & $7.0 \%$ & $28.0 \%$ & $26.0 \%$ & $39.0 \%$ & $100.0 \%$ \\
\hline
\end{tabular}

With respect to legal and political matter, TABLE 15 on respondent's right to vote indicates that a vast majority (76\%) of employed women expressed that they can always exercise their right to vote in comparison to the response from the women in unemployed group (44\%). The significance of this is also visible in the chi square test $\left(X^{2}=11.433, \mathrm{df}=3, \mathrm{p}=0.010\right)$. The information from TABLE 16 on knowledge about legal right reveals that $14 \%$ of employed women have extensive knowledge about legal right, on the contrary, a lower percentage $(6 \%)$ in the case of unemployed women. The significance evidence of this relationship is also apparent from the results of chi square test $\left(X^{2}=11.344, \mathrm{df}=3, \mathrm{p}=0.010\right)$. 
Table 15: Right to Vote

\begin{tabular}{|c|c|c|c|c|c|c|c|}
\hline & & & not at all & sometimes & often & always & Total \\
\hline \multirow{4}{*}{$\begin{array}{l}\text { Current } \\
\text { Employment } \\
\text { Status }\end{array}$} & \multirow[t]{2}{*}{ Unemployed } & Count & 2 & 9 & 17 & 22 & 50 \\
\hline & & $\%$ within Current Employment Status & $4.0 \%$ & $18.0 \%$ & $\begin{array}{r}34.0 \\
\%\end{array}$ & $44.0 \%$ & $\begin{array}{r}100.0 \\
\%\end{array}$ \\
\hline & \multirow[t]{2}{*}{ Employed } & Count & 2 & 3 & 7 & 38 & 50 \\
\hline & & $\%$ within Current Employment Status & $4.0 \%$ & $6.0 \%$ & $\begin{array}{r}14.0 \\
\%\end{array}$ & $76.0 \%$ & $\begin{array}{r}100.0 \\
\%\end{array}$ \\
\hline \multirow{2}{*}{\multicolumn{2}{|c|}{ Total }} & Count & 4 & 12 & 24 & 60 & 100 \\
\hline & & $\%$ within Current Employment Status & $4.0 \%$ & $12.0 \%$ & $\begin{array}{r}24.0 \\
\%\end{array}$ & $60.0 \%$ & $\begin{array}{r}100.0 \\
\%\end{array}$ \\
\hline
\end{tabular}

Table 16: Knowledge about Legal Right

\begin{tabular}{|c|c|c|c|c|c|c|c|}
\hline & & & not aware & $\begin{array}{c}\text { limited } \\
\text { knowledge }\end{array}$ & $\begin{array}{c}\text { average } \\
\text { knowledge }\end{array}$ & $\begin{array}{l}\text { extensive } \\
\text { knowledge }\end{array}$ & Total \\
\hline \multirow{4}{*}{$\begin{array}{l}\text { Current } \\
\text { Employment } \\
\text { Status }\end{array}$} & \multirow[t]{2}{*}{ Unemployed } & Count & 2 & 22 & 23 & 3 & 50 \\
\hline & & $\begin{array}{l}\text { \% within Current } \\
\text { Employment Status }\end{array}$ & $4.0 \%$ & $44.0 \%$ & $46.0 \%$ & $6.0 \%$ & $100.0 \%$ \\
\hline & \multirow[t]{2}{*}{ Employed } & Count & 3 & 7 & 33 & 7 & 50 \\
\hline & & $\begin{array}{l}\% \text { within Current } \\
\text { Employment Status }\end{array}$ & $6.0 \%$ & $14.0 \%$ & $66.0 \%$ & $14.0 \%$ & $100.0 \%$ \\
\hline \multirow{2}{*}{\multicolumn{2}{|c|}{ Total }} & Count & 5 & 29 & 56 & 10 & 100 \\
\hline & & $\begin{array}{l}\% \text { within Current } \\
\text { Employment Status }\end{array}$ & $5.0 \%$ & $29.0 \%$ & $56.0 \%$ & $10.0 \%$ & $100.0 \%$ \\
\hline
\end{tabular}

Lastly on the familial and interpersonal issue two tables demonstrate the difference between employed and unemployed women. In TABLE 17 when respondents were asked if they believed boy child is valuable than a girl child, a significant difference was observed between employed and unemployed as $\left(Z^{2}=9.411, \mathrm{df}=3\right.$, $\mathrm{p}=0.024$ ). Though majority of the respondents of both categories said not at all (Unemployed $64 \%$ and Employed $88 \%$ ) but the percentage is higher for employed. For the unemployed respondents $36 \%$ believed that boy child is more valuable than girl child but for employed only $12 \%$ share the same thought.

Table 17: Believe That Boy Child Is Valuable Than A Girl Child

\begin{tabular}{|c|c|c|c|c|c|c|c|}
\hline & & & always & often & sometimes & not at all & Total \\
\hline \multirow{2}{*}{$\begin{array}{l}\text { Current } \\
\text { Employment } \\
\text { Status }\end{array}$} & Unemployed & Count & 2 & 5 & 11 & 32 & 50 \\
\hline & Employed & Count & 2 & 2 & 2 & 44 & 50 \\
\hline \multirow{2}{*}{\multicolumn{2}{|c|}{ Total }} & Count & 4 & 7 & 13 & 76 & 100 \\
\hline & & $\%$ within Current Employment Status & $4.0 \%$ & $7.0 \%$ & $13.0 \%$ & $76.0 \%$ & $100.0 \%$ \\
\hline
\end{tabular}

Table 18: Physical Mistreatment by Family Member

\begin{tabular}{|c|c|c|c|c|c|c|c|}
\hline & & & always & often & sometimes & not at all & Total \\
\hline \multirow{2}{*}{$\begin{array}{l}\text { Current } \\
\text { Employment } \\
\text { Status }\end{array}$} & Unemployed & Count & 5 & 3 & 8 & 34 & 50 \\
\hline & Employed & Count & 0 & 0 & 1 & 49 & 50 \\
\hline \multirow{2}{*}{\multicolumn{2}{|c|}{ Total }} & Count & 5 & 3 & 9 & 83 & 100 \\
\hline & & $\%$ within Current Employment Status & $5.0 \%$ & $3.0 \%$ & $9.0 \%$ & $83.0 \%$ & $100.0 \%$ \\
\hline
\end{tabular}

Having a look at the table 18 regarding physical abuse, it has been observed that $32 \%$ women in the unemployed group have experienced more or less physical mistreatment, which is significantly high than employed women $(2 \%)$. This relationship is has been found significant from the chi square test $\left(Z^{2}=16.155\right.$, df $=3, \mathrm{p}=0.001)$.

\section{Conclusion}

For a developing country like Bangladesh women participation is crucial for the growth of economy. In order to measure socio economic empowerment of women, factors such as decision making regarding house hold issues, control over resources, access to resources, mobility, self respect and knowledge on legal and political activities are considered. In this study, it has been observed that urban employed women are more empowered than unemployed women in certain decision making issues like decision about purchasing expensive items, child health and employment. It is also portrayed that the employed women has more access and control over resources like access to their property, opportunity to save, control family budget, own property and saving and purchase of gift items than the unemployed women. Moreover regarding mobility employed women have more freedom to go outside and are more frequent in visiting different places. According to factor 
self respect, employed women expect more participation from husband in house hold chores and they also obtain greater appreciation from family. Greater knowledge, awareness and practice about the legal rights are also evident in the case of employed women. The study also highlighted the facts that physical abuse has relationship with the employment status of the urban women.

Based on the empirical result, it can be concluded that the employment plays a positive role for the women to be empowered in Dhaka City. For increasing empowerment of the unemployed women awareness programs should be initiated by the institutions of the community. Moreover positive attitude towards gender equality can be developed through programs in the place of work of the male members. This paper can help the policy makers focus their strategy in order to empower unemployed urban women. From this research it is observed that several factors of the empowerment indicators have no evidence of significant relationship with the employment status of urban women which indicates that only employment will not uplift the empowerment status of women. Social awareness through formal and informal education can also have an impact on women empowerment. Future studies can be pursued on social factors other than employment that affects women empowerment.

\section{References}

[1] C. A. Al-Hossienie, Socio-Economic Impact of Women Entrepreneurship in Sylhet City, Bangladesh, Bangladesh Development Research Working Paper Series (BDRWPS), 2011

[2] M. M. Haque, T.M Islam, M. I. Tareque, and M. G. Mostofa, Women Empowerment or Autonomy: A Comparative View in Bangladesh Context, Bangladesh e-Journal of Sociology, 8 (17), 2011

[3] S. Batliwala, The Meaning of Women's Empowerment: New Concepts from Action, in G. Sen, A. Germain and L.C. Chen (Ed.) Population Policies Reconsidered: Health, Empowerment and Rights, (Cambridge: Harvard University Press, 1994)

[4] M. Hossain, and W. Jaim, Empowering Women to Become Farmer Entrepreneur, Proc. IFAD Conf. on New Directions for Smallholder Agriculture, Rome, Italy, 2011.

[5] H. Khan, NGOs and Gender Development, the Case of AKRSP in District Chitral, NWFP, Pakistan, Lahore Journal of Economics, 11, 2006, 81-98.

[6] N. Kabeer, Women, Wages and Intra-household Power Relations in Urban Bangladesh, Development and Change 28(2), 1997.

[7] P. Kantor, Women's empowerment through home-based work: Evidence from India, Development and Change 34(3), 2003, 425445 .

[8] P. Sen, Enhancing Women's Choices in Responding to Domestic Violence in Calcutta: A Comparison of Employment and Education, European Journal of Development Research 11(2), 1999, 65-86.

[9] R. Pearson, Women, work and empowerment in a global era, Ids Bulletin- Institute of Development Studies 35(4), 2004.

[10] Bangladesh Bureau of Statistics, Report on Labor Force Survey 2010, August 2011.

[11] Bangladesh Bureau of Statistics, Report on Violence against Women Survey 2011, December 2013.

[12] M. E. Khan and A. Aeron, Prevalence, nature and determinants of violence against women in Bangladesh, The Journal of Family Welfare, 52, 2006, 33-51.

[13] N. Kabeer, Resources, agency, achievements: reflections on the measurement of women's empowerment, in: B. Sevefjord and B. Olsson (Ed.) Discussing Women's Empowerment - Theory and Practice, (Sweden: Swedish International Development Agency. 2002) 17-57.

[14] R. Musokotwane, R.M. Siwale, and B. Nkhata, Gender Awareness and Sensitization in Basic Education, Proc. of People's Action Forum UNESCO Basic Education, 2001.

[15] G. Sen, Empowerment as an Approach to Poverty, Human Development Report, Background Paper, UNDP, New York, 1997, in: BRAC, ICDDRB, Joint Research Project Working Paper No 28(1), 1998.

[16] K. O. Mason, and H. L. Smith, Women's empowerment and social context: results from five Asian Countries, Gender and Development Group, World Bank, Washington, DC, 2003.

[17] N. Kabeer, The conditions and consequences of choice: reflections on the measurement of women's empowerment, UNRISD Discussion Paper No. 108, August 1999 UNRISD Geneva.

[18] B. GU, Empowerment of Rural Women through Income Generating Activities in Gadag District on Northern Karnataka, University of Agricultural Sciences, 2005.

[19] S. Amin and A. Pebley, Gender Inequality within Households: The Impact of Women's Development Program in 36 Bangladeshi Villages, Special Issue on Women, Development and Change The Bangladesh Development Studies, The Bangladesh Institute of Development Studies (BIDS), 22 (2\&3), 1994, 121-155.

[20] S. M. Hashemi, S. R. Schuler and A. P. Riley, Rural Credit Programs and Women's Empowerment in Bangladesh, World Development, 24(4), 1996, 635-653.

[21] R. Naved, Empowerment of Women: Listing to the Voices of Women. In Amin, The Bangladesh Development Studies, Special Issue on Women, Development and Change, 22(2\&3), 1994, 121-155.

[22] M. Pitt, S. R. Khandker, J. Cartwright, Empowering Women with Microfinance: Evidence from Bangladesh, Economic Development and Cultural Change, 2006, 791- 831.

[23] Aloysius P. Fernandez, History and spread of the self-help affinity group movement in India: The role played by International Fund for Agricultural Development (IFAD), Occasional Papers No.3, 2006.

[24] G. A. Parvin, S. M. R. Ahsan, \& M. R. Chowdhury, Women Empowerment Performance of Income Generating Activities Supported by Rural Women Employment Creation Project (RWECP): A Case Study in Dumuria Thana, Bangladesh, Journal of Geo-environment, 4, 2004, 47-62.

[25] A. Scoggins, Women's empowerment through micro-finance. The case of the micro-credit project for women, Occasional paper No.2, Abstracts of research findings from South Asia, 1999.

[26] Niaz Hussain Malik and Muhammad Luqman, Impact of microcredit on women empowerment: a review paper, Pakisthan Journal of Agricultural Science, 42 (3-4), 2005.

[27] CIDA, Microcredit and equality between women and men, CIDA equality prompt \# 6. Canadian International Development Agency, Stockholm, Sweden, 1998. 
[28] Frank Tesoriero, Strengthening communities through women's self help groups in South India, Community Development Journal, 41(3), 2006, 321-333.

[29] C. S. Reddy and Sandeep Manak, Self-Help Groups: A Keystone of Microfinance in India - Women empowerment \& social security, Mahila Abhivruddhi Society, Andhra Pradesh (APMAS), Hyderabad, October 2005

[30] H. Zaman, Assessing the poverty and vulnerability impact of microcredit in Bangladesh: a case study of Bangladesh Rural Advancement Committee (BRAC), unpublished background paper for World Bank, World Development Report, Washington, DC, 2001.

[31] Sangeeta Arora, and Meenu, Women Empowerment through Microfinance Intervention in the Commercial Banks: An Empirical Study in the Rural India with Special Reference to the State of Punjab, International Journal of Economic Research. 2(2), 2011, 3545.

[32] Ranjula Bali Swain \& Fan Yang Wallentin, Factors empowering women in Indian self-help group programs, International Review of Applied Economics. 26(4), 2012, 425-444.

[33] N. Kabeer, Discussing women's empowerment: Theory and practice, Swedish international development cooperation agency (Sida), 2001.

[34] L. Hultberg, Women Empowerment in Bangladesh: A Study of the Village Pay Phone Program, Independent thesis Basic level (degree of Bachelor), Jönköping University, Sweden , 2008

[35] D. Banu, F. Fehmin, H. Altaf, and A. Shahnuj, Empowering Women in Rural Bangladesh: Impact of Bangladesh Rural Advancement Committee's (BRAC's) Program, Journal of international women's studies, 2(24), 2001.

[36] M. Dutta, Women's Employment and Its Effects on Bengali Households of Shillong, India, Journal of Comparative Family Studies 31(2), 2000, 217-229.

[37] S. Salway, S. Jesmin, Women's employment in urban Bangladesh: A challenge to gender identity? , Development and Change 36(2), 2005, 317-349.

[38] B. Baruah, Earning their keep and keeping what they earn: A critique of organizing strategies for South Asian women in the informal sector, Gender Work and Organization, 11(6), 2004, 605-626.

[39] U. Sekaran, Research methods for business: A skill-building approach (United Kingdom, Wiley \& Sons Ltd, 2003). 